\title{
LUTEINIZING HORMONE, OESTROGEN AND PROGESTERONE LEVELS IN PERIPHERAL SERUM OF ANOESTROUS AND CYCLIC EWES AS DETERMINED BY RADIOIMMUNOASSAY
}

\author{
P. YUTHASASTRAKOSOL,* W. M. PALMER* AND \\ B. E. HOWLAND $\dagger$ \\ Departments of *Animal Science and $\dagger$ Oral Biology, \\ University of Manitoba, Winnipeg, Manitoba, Canada R3T $2 \mathcal{N} 2$
}

(Received 23rd Fuly 1974)

\begin{abstract}
Summary. Jugular vein blood was collected daily from four mature ewes throughout anoestrus and the first oestrous cycle of the breeding season until 4 days after the second oestrus. The levels of oestrogen, progesterone and LH were determined by radioimmunoassay. There were fluctuations in the $\mathrm{LH}$ level throughout most of the observed anoestrous period with a mean \pm S.E. value of $2.3 \pm 0.9 \mathrm{ng} / \mathrm{ml}$. High LH values of $20.0,41.2$ and $137.5 \mathrm{ng} / \mathrm{ml}$ were observed in three ewes on Day -24 of anoestrus. A brief minor rise in progesterone level was also observed around this period. Progesterone levels were consistently low $(0.11 \pm 0.01 \mathrm{ng} / \mathrm{ml})$ before Day -25 of anoestrus. A major rise occurred on Day -12 of anoestrus and this was followed by patterns similar to those that have been previously reported for the oestrous cycle of the ewe. Random fluctuations of oestrogens deviating from a mean level of $4.40 \pm$ $0.1 \mathrm{pg} / \mathrm{ml}$ were observed during anoestrus and the mean level during the period from the first to the second oestrus was $5.2 \pm 0.3 \mathrm{pg} / \mathrm{ml}$. A welldefined peak of $13.3 \pm 0.7 \mathrm{pg} / \mathrm{ml}$ was seen in all ewes on the day of the second oestrus. Results of the present study suggest that episodic releases of LH occur during anoestrus and periods of low luteal activity. The fluctuations in LH levels, as observed during the period of low luteal activity, i.e. before Day -25 of anoestrus, were less pronounced during the periods of high luteal activity. The view that luteal activity precedes the first behavioural oestrus of the breeding season is supported.
\end{abstract}

\section{INTRODUCTION}

Reports of various investigators regarding the level of LH (Geschwind \& Dewey, 1968; Niswender, Roche, Foster \& Midgley, 1968; Goding, Catt, Brown, Kaltenbach, Cumming \& Mole, 1969), oestrogens (Moore, Barrett, Brown, Schindler, Smith \& Smyth, 1969; Scaramuzzi, Caldwell \& Moor, 1970; Obst, Seamark \& Brown, 1971; Cox, Mattner, Shutt \& Thorburn, 1971; Bjersing \& co-authors, 1972) and progesterone (Thorburn, Bassett \& Smith, 
1969; Stabenfeldt, Holt \& Ewing, 1969; McNatty, Revfeim \& Young, 1973) in peripheral and ovarian blood have established the endocrinological events during the ovine oestrous cycle, but the relationships of these three hormones during anoestrus are not well documented.

In previous studies, $\mathrm{LH}$ in ovine peripheral blood during anoestrus was found to be low (Goding et al., 1969; Gay, Niswender \& Midgley, 1970; Roche, Foster, Karsch, Cook \& Dziuk, 1970; Reeves, Arimura, Schally, Kragt, Beck \& Casey, 1972). Recently, Palmer, Phillips, Howland \& Ibrahim (1972), Fell, Beck, Brown, Catt, Cumming \& Goding (1972) and Butler, Malven, Willett \& Bolt (1972) have presented some evidence which indicates that episodic LH releases occur in anoestrous and anovulatory ewes. Progesterone has been found to be at basal levels throughout anoestrus with some elevations occurring before the first behavioural oestrus of the breeding season (Thorburn et al., 1969). Reeves, Tarnavsky \& Chakraborty (1974) reported that the circulating levels of oestrogens were very low during anoestrus. This report was, however, based on data obtained from only one day during early, mid- and late anoestrus, respectively.

In the present study, the levels of $\mathrm{LH}$, oestrogens and progesterone were determined by radioimmunoassay in the peripheral serum of ewes from midanoestrus and late anoestrus until 4 days after the second oestrus of the breeding season.

\section{MATERIALS AND METHODS}

Data were obtained from four mature ewes of mixed breeding housed in a barn under natural lighting conditions with free access to hay and water. A raddled vasectomized ram was maintained continuously with the ewes throughout the observation period. Blood samples were collected daily from 4 July to 20 July and then from 31 August until 4 days after each ewe exhibited its second oestrus of the breeding season. In order to define the LH peak more clearly, samples were taken two or four times per day during the 24-hr period immediately after the onset of oestrus. Jugular vein blood $(30 \mathrm{ml})$ was collected by venepuncture from each ewe and allowed to clot overnight at $4^{\circ} \mathrm{C}$. The serum was then separated from the clot by centrifugation and stored at $-20^{\circ} \mathrm{C}$ until assay. Earlier studies in this laboratory indicated that steroid values, as determined in serum samples handled in this manner, did not differ from those determined in plasma taken at the same time from the same animal in which the plasma had been separated immediately after collection from the heparinized whole blood.

\section{Hormone assay}

Serum oestrogens were determined by radioimmunoassay which measured total oestrogens (RIA) as previously described for the chicken by Yu, Yuthasastrakosol, Marquardt \& Palmer (1974) and the sheep (Yuthasastrakosol, Howland, Simaraks \& Palmer, 1974). Anti-oestradiol-17 $\beta$-BSA serum (No. 029-14) was used at an initial dilution of $1: 100,000$. The intra-assay coefficient of variation for ovariectomized ewe serum fortified with $6.2,12.5$ and $25.0 \mathrm{pg}$ oestradiol-17 $\beta$ was $6.9,10.5$ and $7.6 \%$, respectively. The inter-assay coefficient of variation for the determination of 25.0 and $50.0 \mathrm{pg}$ oestradiol-17 $\beta$ 
added to double-distilled water in five separate assays was 9.3 and $7.9 \%$, respectively.

The RIA procedure for serum progesterone was that of Abraham, Swerdloff, Tulchinsky \& Odell (1971) as modified by Yuthasastrakosol et al. (1974) and was used without column chromatography. A highly specific (Niswender, 1973) anti-progesterone-6 $\beta$-BSA serum (No. 869) was used at an initial dilution of $1: 3000$. The progesterone concentration in serum pooled from ewes in various

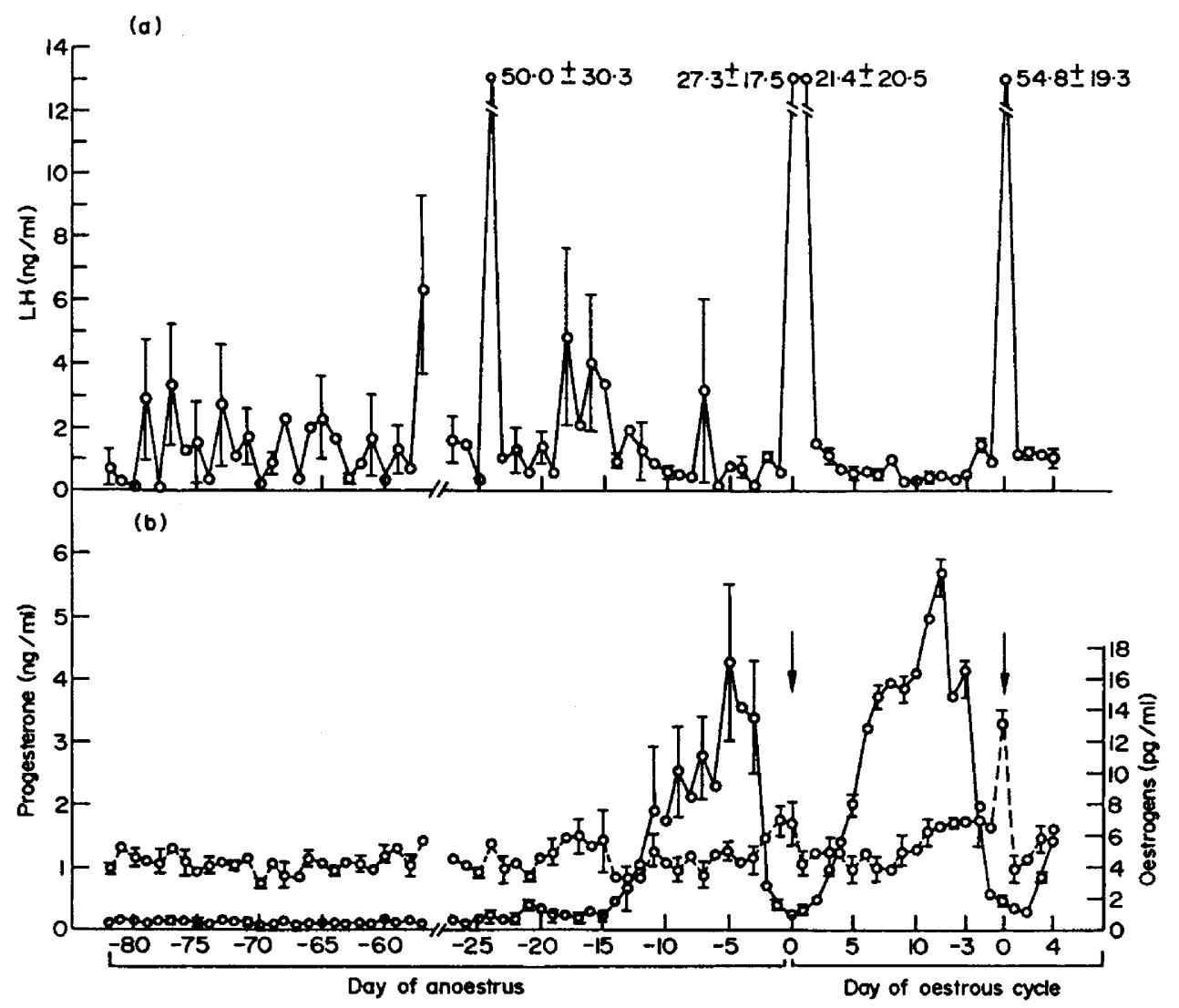

Text-Fig. I. The mean ( \pm S.E.) daily peripheral levels of (a) serum LH, (b) oestrogen $(--)$ and progesterone $(-)$ of four ewes during anoestrus and the first oestrous cycle of the breeding season $(0=$ day of oestrus). The days of anoestrus were normalized to the first oestrus of the breeding season and the last 3 days of the cycle were related to the second oestrus. For Days -71 to -25 , number of ewes $=3$; Day -13 , number of ewes $=2$. The arrows signify the onset of oestrus.

reproductive states determined in sixteen separate assays was $2 \cdot 22 \pm 0 \cdot 04 \mathrm{ng} / \mathrm{ml}$ with a coefficient of variation of $7.5 \%$. Similarly, progesterone concentration of serum pooled from early and mid-anoestrous ewes as determined in four separate assays gave a mean value of $0 \cdot 18 \pm 0.01 \mathrm{ng} / \mathrm{ml}$ and a coefficient of variation of $14.4 \%$.

Serum LH concentrations were determined by a double antibody RIA using procedures previously described (Howland, 1972). Anti-ovine LH serum (No. 
15) was used at an initial dilution of $1: 100,000$. The LH concentrations were expressed in terms of NIH-LH-S14 standard.

\section{RESULTS}

The mean daily serum $\mathrm{LH}$, oestrogen and progesterone levels in the four anoestrous ewes are represented in Text-fig. 1. The day of anoestrus is normalized to the first detected behavioural oestrus of the breeding season, and the last 3

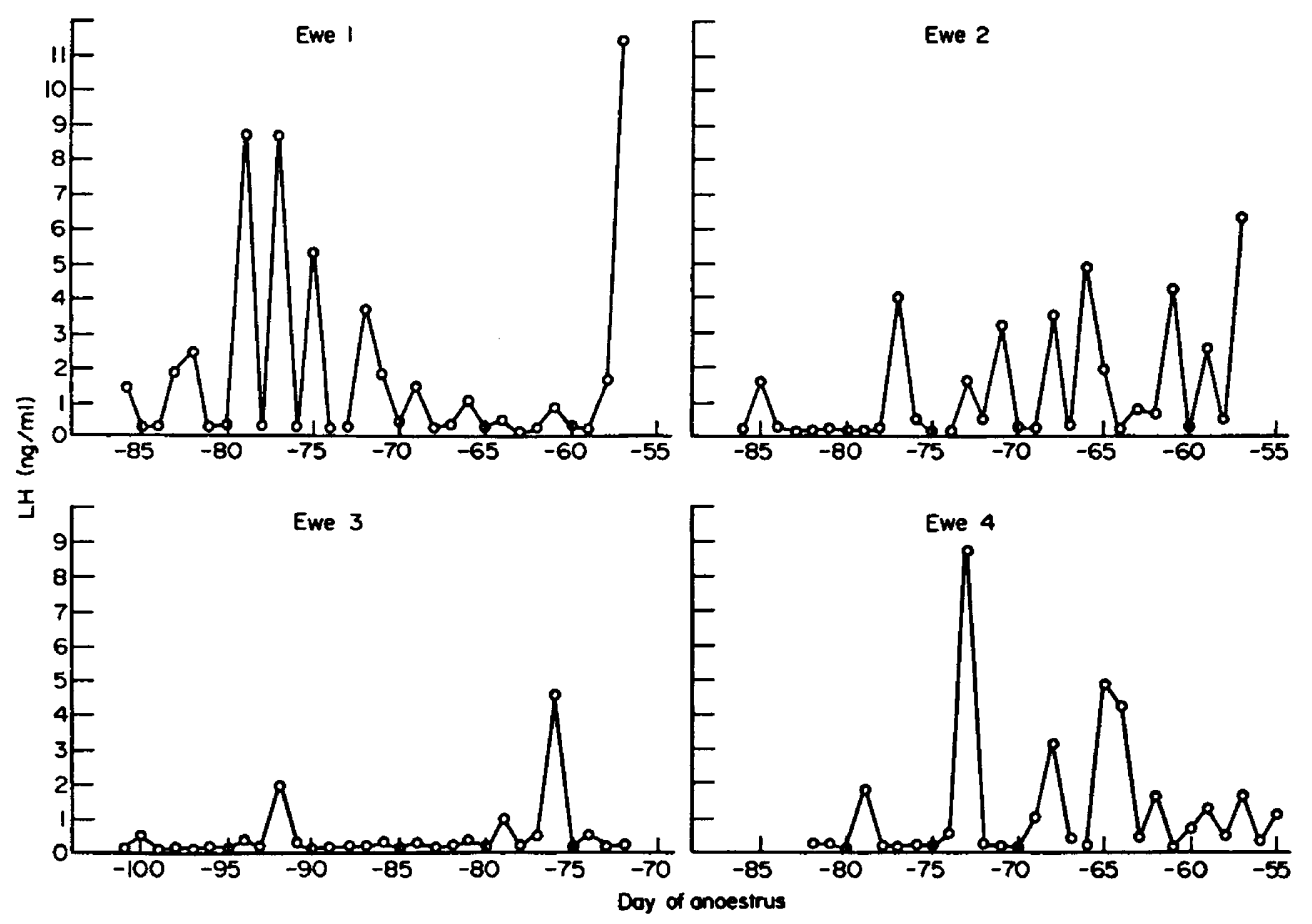

TEXT-FIG. 2. The daily peripheral serum LH of four ewes during the period of anoestrus from about Days -85 to -55 before the first behavioural oestrus of the breeding season.

days of the oestrous cycle are related to the second oestrus. The interval between the first and second oestrous periods was 16, 17, 16 and 18 days for Ewes 1, 2, 3 and 4, respectively. The LH levels as seen in the individual ewes from approximately Days -85 to -55 of anoestrus are shown in Text-fig. 2 .

It is quite obvious that there are fluctuations in the peripheral serum LH levels for most of the observed anoestrous period (Text-figs 1 and 2). The mean \pm S.E. value during this time was $2.3 \pm 0.9 \mathrm{ng} / \mathrm{ml}$. Individually, Ewes 1,2 and 4 showed peak levels of $20.0,41.2$ and $137.5 \mathrm{ng} / \mathrm{ml}$ (Text-fig. 3 ), respectively, on Day -24 of anoestrus. Marked fluctuations also occurred at about Days -16 to -18 of anoestrus. Ewes 2 and 4 showed LH peaks associated with both oestrous periods, while only one peak was observed to be associated with either period in Ewes 1 and 3. Peaks were probably missed at the other times, because 


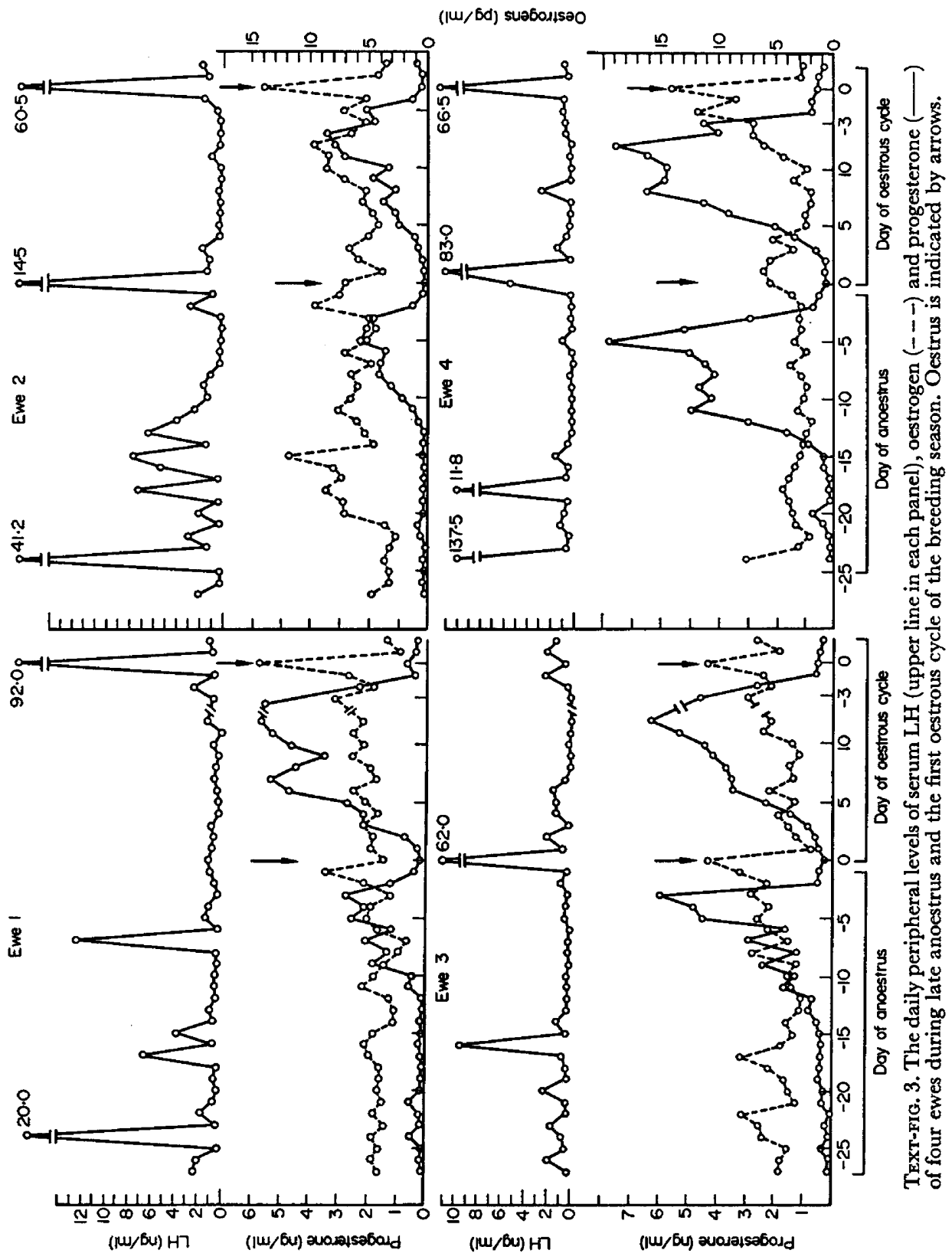


of insufficient sampling frequency or they may have occurred before the onset of oestrus and were therefore not detected.

Changes in the progesterone levels were not observed before Day -25 of anoestrus (Text-fig. 1) and remained at a basal level $(0 \cdot 10 \pm 0.01 \mathrm{ng} / \mathrm{ml})$. What appeared to be a brief, minor rise in progesterone level was observed around Days -25 and -21 of the anoestrus in all ewes (Text-fig. 3). This was followed by the first major rise which began on Day -12 of anoestrus and reached a peak on Day -5 of anoestrus (Text-fig. 1). Levels then dropped to an average of $0.25 \pm 0.05 \mathrm{ng} / \mathrm{ml}$ on the day of the first oestrus and then again increased rapidly after Day 2 to a peak on Day 12 of the oestrous cycle. Peripheral serum levels then rapidly declined on Day -2 to a mean of $0.45 \pm 0.09 \mathrm{ng} / \mathrm{ml}$ on the day of the second oestrus of the breeding season (Text-fig. 1). Maximum values of $4 \cdot 28 \pm 1.27$ and $5 \cdot 67 \pm 0.94 \mathrm{ng} / \mathrm{ml}$ were observed during Day -5 of anoestrus and Day 12 of the oestrous cycle, respectively.

The composite picture (Text-fig. 1) of the mean oestrogen levels of the four ewes showed no recognizable pattern throughout anoestrus and the mean concentration during this period was $4 \cdot 40 \pm 0 \cdot 1 \mathrm{ng} / \mathrm{ml}$. The only major and welldefined peak, which rose to a mean of $13.3 \pm 0.7 \mathrm{pg} / \mathrm{ml}$, was observed to occur in all ewes on the day of the second oestrus. Individually (Text-fig. 3), a minor rise ranging from Day -2 of anoestrus to the day of the first oestrus was seen in Ewes 1, 2 and 3. The mean level during the period from the first to the second oestrus was $5 \cdot 2 \pm 0 \cdot 3 \mathrm{pg} / \mathrm{ml}$ (Text-fig. 1 ).

\section{DISCUSSION}

Contrary to earlier reports (Goding et al., 1969; Gay et al., 1970; Roche et al., 1970; Reeves et al., 1972), our results have clearly shown that there is a fluctuation in the LH levels in the peripheral serum throughout most of anoestrus. Reeves et al. (1972) observed some fluctuations in the cavernous sinus serum, but not in the peripheral serum and attributed their findings to the possible contamination of the cavernous sinus serum with intracellular fluid from the anterior pituitary during the collection. The present findings are in agreement with the findings in anovulatory (Butler et al., 1972) and anoestrous (Fell et al., 1972) ewes.

In the present study, the fluctuations in LH release appeared to be somewhat depressed during the period of high luteal activity, which resulted from either the 'silent' ovulation (or luteinization of follicles), or the ovulation which was accompanied by behavioural oestrus. Similarly, Cicmanec \& Niswender (1973) noted greater fluctuations in LH levels when luteal activity was low during the oestrous cycle. Butler et al. (1972) observed relatively stable LH levels on Day 8 of the cycle when luteal activity was high.

It is interesting to note the exceptionally high $\mathrm{LH}$ levels that were observed on Day -24 of anoestrus in three of four ewes (Text-fig. 3) and the apparent association of these values with the brief, minor rise in progesterone levels. It has also been generally agreed that most ewes commence their ovarian cycles with at least one preliminary ovulation before the first behavioural oestrus of the breeding season (Hunter, 1968; Foote, Sefidbakht \& Madsen, 1970). It is, 
therefore, plausible to assume that our findings of the pattern of progesterone levels which were observed from Day -14 of anoestrus to the day of the first oestrus (Text-figs 1 and 3) could have been the result of CL formed by 'silent' ovulation. It could, however, have resulted from luteinization of follicles, without ovulation occurring.

The present findings on progesterone levels during anoestrus agreed generally with those of Thorburn et al. (1969) who observed a minor and brief rise in progesterone level of 1 day's duration which was then followed shortly by a major rise before the onset of the breeding season. Walton, Cunningham, Temple $\&$ Bowman (1974) also observed a rise in progesterone level which was about one-third of the magnitude of that observed during the luteal phase of the normal oestrous cycle and occurred about 5 days before the first ovulation, or about 23 to 24 days before the first behavioural oestrus. The phenomenon of a small and brief rise in progesterone level before the first ovulation after parturition has been observed also in cows (Pope, Gupta \& Munro, 1969; Donaldson, Bassett \& Thorburn, 1970; Robertson, 1972). Since the ovaries were not examined in the present study, it cannot be unequivocally assumed that ovulation actually occurred during anoestrus, on the basis of progesterone elevation alone. Thus, the source and significance of this phenomenon and whether it is preceded by ovulation or luteinization of follicles cannot be explained at present. In view of exceptionally high LH levels observed on Day -24 of anoestrus, it is possible that the minor rise in progesterone in sheep is part of a very long luteal phase following 'silent' ovulation. For some reason, however, the corpus luteum does not function at full capacity until some days later. The pattern of progesterone levels observed during the oestrous cycle in this study was similar to that previously reported for the oestrous cycle of the ewe (Stabenfeldt $e t$ al., 1969; Thorburn et al., 1969; Robertson \& Sarda, 1971; McNatty et al., 1973).

The lack of any apparent association between oestrogen levels and the episodically high LH levels observed during anoestrus, particularly on Day -24 of anoestrus, or the first period of oestrus did not exclude a possible oestrogenic influence. It is possible that there is an increase in the sensitivity of the hypothalamus or anterior pituitary to oestrogen because of external stimuli, such as decreasing daylight at the critical period around Day -24 of anoestrus. Beck \& Reeves (1973) reported no significant differences in the LH concentration elicited by oestradiol at various stages of anoestrus but suggested that treatments in late anoestrus may have elicited higher $\mathrm{LH}$ concentrations than those in early or mid-anoestrus.

The high LH levels observed on Day -24 of anoestrus in three of four ewes suggest that the first ovulation of the breeding season may occur at a particular hour of the day, as speculated by Robertson \& Rakha (1966), since the possibility of the detection of LH peaks in three of four ewes by chance alone from the single sampling would be very small.

Several investigators have reported that the peak oestrogen level in the ovarian venous blood occurs 1 day before the onset of oestrus (Moore et al., 1969; Scaramuzzi et al., 1970; Cox et al., 1971; Bjersing et al., 1972). Our results from peripheral serum, however, indicated otherwise. The oestrogen peak levels were observed on the day of oestrus which is in agreement with the results reported 
by Pant, Hopkinson \& Fitzpatrick (1972). These investigators suggested that the difference in the time that the oestrogen peak was observed between ovarian and peripheral plasma might have been caused by the surgery and anaesthesia involved in the collections of ovarian venous blood, which might have changed the length of the oestrous cycle in the ewes.

The mean oestrogen level of $13.3 \pm 0.7 \mathrm{pg} / \mathrm{ml}$ observed in the peripheral blood on the day of the second oestrus in this study compares favourably with the theoretical value of $12.0 \mathrm{pg} / \mathrm{ml}$, as calculated by Goding, Baird, Cumming \& McCracken (1971). This represents a value which is much lower than those reported previously by other investigators (Obst et al., 1971; Pant et al., 1972). In comparison with the mean oestrogen level observed during anoestrus or the inter-oestrous period, it would seem that the peak oestrogen level in the peripheral blood at the time of oestrus is only about three times higher than the basal level.

While the present study does not present any new evidence as to the possible mechanisms involved in the initiation of the onset of the breeding season in sheep, it appears to suggest that episodic releases of $\mathrm{LH}$ occur during anoestrus and the period of low luteal activity. The results support the view that luteal activity precedes the first behavioural oestrus of the breeding season.

\section{ACKNOWLEDGMENTS}

This study was supported by grants from the National Research Council of Canada (A6248 and A6251) and the University of Manitoba Research Fund. The authors gratefully acknowledge the supply of anti-progesterone-6 $\beta$-BSA serum (No. 869) and anti-ovine LH serum (No. 15) provided by Dr G. D. Niswender, Colorado State University, the anti-oestradiol-17 $\beta$-BSA serum (No. 029-14) kindly donated by Dr B. V. Caldwell, Yale University, and the NIHLH-S14 standard supplied by the Endocrine Study Section, NIH, Bethesda, Maryland. Appreciation is expressed to Mr A. Klassen and Mr S. Simaraks for other technical assistance.

\section{REFERENCES}

Abraham, G. E. Swerdloff, R., Tulchinsky, D. \& Odell, W. D. (1971) Radioimmunoassay of plasma progesterone. Endocrinology, 32, 619-624.

Beck, T. W. \& REEves, J. J. (1973) Serum LH in ewes treated with various dosages of $17 \beta$-estradiol at 3 stages of the anestrus season. F. Anim. Sci. 36, 566-570.

Bjersing, L., Hay, M. F., Kann, G., Moor, R. M., Naftolin, F., Scaramuzzi, R. J., Short, R. V. \& YoungLaI, E. V. (1972) Changes in gonadotrophins, ovarian steroids and follicular morphology in sheep at oestrus. 7. Endocr. 52, 465-479.

Butler, W. R., Malven, P. V., Willett, L. B. \& Bolt, D. J. (1972) Patterns of pituitary release and cranial output of LH and prolactin in ovariectomized ewes. Endocrinology, 91, 793-801.

Gramanec, J. L. \& Niswender, G. D. (1973) Arterial-venous differences in gonadotrophin concentration across the ovary of sheep during different reproductive states. Proc. Soc. exp. Biol. Med. 144, 99-105.

Cox, R. I., Matrner, P. E., Shutt, D. A. \& Thorburn, G. D. (1971) Ovarian secretion of oestradiol during the oestrous cycle in the ewe. $\mathcal{F}$. Reprod. Fert. 24, 133-134.

Donaldoson, L. E., Bassett, J. M. \& Thorburn, G. D. (1970) Peripheral plasma progesterone concentration of cows during puberty, oestrous cycles, pregnancy and lactation, and the effects of under nutrition or exogenous oxytocin on progesterone concentration. F. Endocr. 48, 599-614.

Fell, L. R., Beck, C., Brown, J. M., Catt, K. J., Cumming, I. A. \& Goding, J. R. (1972) Solid-phase radioimmunoassay of ovine prolactin in antibody-coated tubes. Prolactin secretion during estradiol treatment at parturition and during milking. Endocrinology, 91, 1329-1336. 
Foote, W. C., Sefidbakrt, N. \& Madsen, M. A. (1970) Puberal estrus and ovulation and subsequent estrous cycle patterns in the ewe. 7 . Anim. Sci. 30, 86-90.

Gay, V. L., Niswender, G. D. \& Midgley, A. R., JR (1970) Response of individual rats and sheep to one or more injections of hypothalamic extracts as determined by radioimmunoassay of plasma LH. Endocrinology, 86, 1305-1312.

Geschwind, I. I. \& Dewey, R. (1968) Dynamics of LH secretion in the cycling ewe: a radioimmunoassay study. Proc. Soc. exp. Biol. Med. 129, 451-455.

Goding, J. R., Baird, D. T., Gumming, I. A. \& McCracken, J. A. (1971) Functional assessment of autotransplanted endocrine organs. Acta endocr., Copenh. Suppl. 158, 169-199.

Goding, J. R., Catt, K. J., Brown, J. M., Kaltenbach, C. C., Gumming, I. A. \& Mole, B. J. (1969) Radioimmunoassay for ovine LH. Secretion of LH during estrus and following estrogen administration in sheep. Endocrinology, 85, 133-142.

Howland, B. E. (1972) Effect of restricted feed intake on LH levels in female rats. F. Anim. Sci. 34, $445-447$.

Hunter, G. L. (1968) Increasing the frequency of pregnancy in sheep. II. Artificial control of rebreeding and problems of conception and maintenance of pregnancy during the post-partum period. Anim. Breed. Abstr. 35, 533-553.

McNatty, K. P., Revfeim, K. J. A. \& Young, A. (1973) Peripheral plasma progesterone concentrations in sheep during the oestrous cycle. F. Endocr. 58, 219-225.

Moore, N. W., Barrett, S., Brown, J. B. Schindler, I., Smith, M. A. \& Smyth, B. (1969) Oestrogen and progesterone content of ovarian vein blood of the ewe during the oestrous cycle. $\mathcal{F}$. Endocr. 44, 55-62.

Niswender, G. D. (1973) Influence of the site of conjugation on the specificity of antibodies to progesterone. Steroids, 22, 413-424.

Niswender, G. D., Roche, J. F., Foster, D. L. \& Midgley, A. R. (1968) Radioimmunoassay of serum levels of LH during the cycle and early pregnancy in ewes. Proc. Soc. exp. Biol. Med. 129, 901-904.

Obst, M. J., Seamark, R. F. \& Brown, J. M. (1971) Application of a competitive protein-binding assay for oestrogens to the study of ovarian function in sheep. 7. Reprod. Fert. 24, 140, Abstr.

Palmer, W. M., Phillips, G. D., Howland, B. E. \& Ibrahim, E. A. (1972) Effect of day length on reproduction in ewes. 7. Anim. Sci. 34, 903, Abstr.

Pant, H. C., Hopkinson, C. \& Fitzpatrick, R. J. (1972) Plasma oestradiol, progesterone and luteinizing hormone concentrations during the ovine oestrous cycle. F. Reprod. Fert. 31, 501, Abstr.

Pope, G. S., Gupta, S. K. \& Munro, I. B. (1969) Progesterone levels in the systemic plasma of pregnant, cycling, and ovariectomized cows. 7. Reprod. Fert. 20, 369-381.

Reeves, J. J., Arimura, A., Sghally, A. V., Kragt, G. L., Beck, T. W. \& Casey, J. M. (1972) Effects of synthetic luteinizing hormone-releasing hormone/follicle stimulating hormone-releasing hormone (LH-RH/FSH-RH) on the serum LH, serum FSH and ovulation in anestrous ewes. $\mathcal{J}$. Anim. Sci. 35, 84-89.

Reeves, J. J. Tarnavsky, G. K. \& Chakraborty, P. K. (1974) Serum LH in ewes treated with synthetic luteinizing hormone-releasing hormone (LH-RH/FSH-RH) at three periods of anestrus. 7. Anim. Sci. 38, 369-373.

Robertson, H. A. (1972) Sequential changes in plasma progesterone in the cow during the estrous cycle, pregnancy, parturition, and post-partum. Can. 7. Anim. Sci. 52, 645-658.

Robertson, H. A. \& RAHKA, A. M. (1966) The sequence, time and duration of the release of FSH and LH in relation to oestrus and to ovulation in the sheep. 7 . Endocr. 35, 177-184.

Robertson, H. A. \& SARDA, I. R. (1971) A very early pregnancy test for mammals: its application to the cow, ewe and sow. F. Endocr. 49, 407-419.

Roche, J. F., Foster, D. L., Karsch, F. J., Cook, B. \& Dzruk, P. J. (1970) Levels of LH in sera and pituitaries of ewes during the estrous cycle and anestrus. Endocrinology, 86, 568-572.

Scaramuzzi, R. J., Caldwell, B. V. \& Moor, R. M. (1970) Radioimmunoassay of LH and estrogen during the estrous cycle of the ewe. Biol. Reprod. 3, 110-119.

Stabenfeldt, G. H., Holt, J. A. \& Ewing, L. L. (1969) Peripheral plasma progesterone levels during the ovine estrous cycle. Endocrinology, 85, 11-15.

Thorburn, G. D., Bassetr, J. M. \& SMrth, I. D. (1969) Progesterone concentrations in the peripheral plasma of sheep during the oestrous cycle. 7 . Endocr. 45, 459-469.

Walton, J. S., Cunningham, F. J., Temple, A. \& Bowman, J. C. (1974) Luteinizing hormone and progesterone in the plasma of anoestrous ewes. 7. Endocr. 61, lxxxii, Abstr.

Yu, J. Y.-L., Yuthasastrakosol, P., Marquardt, R. R. \& Palmer, W. M. (1974) Estrogen levels in peripheral plasma of immature female chickens as determined by radioimmunoassay. Endocrinology, 94, 1168-1171.

Yuthasastrakosol, P., Howland, B. E., Simaraks, S. \& Palmer, W. M. (1974) Estrogen-induced LH release in progesterone treated ovariectomized ewes. Can. F. Anim. Sci. (in press). 